Tropical Journal of Pharmaceutical Research, April 2009; 8 (2): 139-143

(C) Pharmacotherapy Group,

Faculty of Pharmacy, University of Benin,

Benin City, 300001 Nigeria.

All rights reserved.

Research Article

Available online at http://www.tjpr.org

\title{
GC-MS Analysis of Insecticidal Leaf Essential Oil of Pyrenacantha Staudtii Hutch and Dalz (Icacinaceae)
}

\author{
Abiodun Falodun ${ }^{1}$, R Siraj ${ }^{2}$, Muhammad lqbal Choudhary ${ }^{2}$ \\ ${ }^{1}$ Department of Pharmaceutical Chemistry, Faculty of Pharmacy, University of Benin, Benin City 300001, Nigeria, \\ ${ }^{2}$ H.E.J. Research Institute of Chemistry, International Center for Chemical Sciences, University of Karachi, Karachi \\ 75270, Pakistan
}

\begin{abstract}
Purpose: Insecticides have been known to cause serious toxicological and environmental problems. Hence, the insecticidal activity and chemical composition of a local medicinal plant was investigated.

Methods: Steam distillation of P.staudtii leaves was carried out using a Clavenger apparatus in order to obtain the volatile oils. Gas chromatography/mass spectrometric (GC/MS) analyses (DB-5 Optima-5 column) of the essential oil were performed and its insecticidal activity determined.

Results: GC-MS spectrometry showed that the major chemical components of the oil were tetradecanoic acid (22\%), hexanoic acid, a-phellandrene (13\%), and citronellol sp. (7\%). The work also revealed significant insecticidal activity of $80 \%$ and $60 \%$ against Rhyzopertha dominica and Tribolium castaneum, respectively.

Conclusion: The study established the chemical composition and insecticidal activity of the essential oil of the plant leaf. Future formulation studies, toxicity profile and possible mechanism of action may lead to the development of a potential insecticidal product.
\end{abstract}

Keywords: Pyrenacantha stautii leaf, GC-MS, Leaf essential oils, Insecticidal. 


\section{Introduction}

The tropical rainforests provide a lot of medicinal plants with potential medicinal properties but the ethno- and phytopharmaceuticals of these plants have not been fully exploited ${ }^{1}$. Their potential medicinal importance is due not only to the species richness of the tropical flora, but also to the diversity of pathogens, parasites and herbivores against which the plants must provide defensive mechanism. Many of the defense chemicals secreted, because of their metabolic precision, can be used to treat humans and prevent or eradicate other organisms $^{2}$

The invasion of food products by insects and moulds contribute greatly to the loss of quality and quantity. Chemicals and fumigants play a vital role in controlling this problem but they have been known to cause serious toxicological and environmental problems, with the consequent carcinogenic effect on $\operatorname{man}^{3}$. The use of plants as an alternative in controlling insects is attracting attention from scientists' worldwide probably due to the non toxicity, affordability and availability of the products $^{3}$.

The plant Pyrencanatha staudtii belongs to the family lcacinaceae and it is a woody climber with green influorescent flowers. The leaves have various therapeutic uses in traditional medicine as a remedy against dysmenorrhoea, malaria, cancer, intestinal colic, miscarriage and ulcer ${ }^{4-6}$. Scanty phytochemical information on this plant exists. However, extensive information about the morphology, ethnomedicine, karyology and ecogeographic differentiation of the genus has been accumulated ${ }^{7-8}$.

The current study is aimed at characterizing the chemical components and insecticidal activity of the essential oil of P.staudtii leaf. Therefore, we report for the first time the separation and identification of the components of leaf essential oils with the aid of GC-MS and other spectroscopic techniques.

\section{Experimental}

\section{Plant collection and identification}

The fresh leaves of the plant were collected in Benin City. Botanical authentification was done at the Forest Research Institute of Nigeria (F.R.I.N., Ibadan), where a herbarium specimen No. FHT 107624 was deposited.

\section{Extraction and isolation of essential oil}

Fresh leaves of Pyrenacantha staudtii were obtained in April, 2008. The plant was dried at room temperature, powdered and hydrodistilled for $6 \mathrm{~h}$ in a Clavenger apparatus. The oil was dried with anhydrous $\mathrm{Na}_{2} \mathrm{SO}_{4}$ to remove moisture. The fraction obtained was stored in a refrigerator at $-4^{\circ} \mathrm{C}$ until use.

\section{Identification of the components}

The identification of the chemical constituents was assigned on the basis of comparison of their retention indices and mass spectra with those given in the literature ${ }^{9-12}$.

\section{Gas chromatography}

Quantitative and qualitative data were determined by GC and GC-MS, respectively. The oil was injected onto a Shimadzu GC-17A system, equipped with an AOC-20i autosampler and a split/ splitless injector. The column used was an DB-5 (Optima-5), $30 \mathrm{~m}$, $0.25 \mathrm{~mm}$ i.d., $0.25 \mu \mathrm{m} d f$, coated with $5 \%$ diphenyl-95\% polydimethylsiloxane, operated with the following oven temperature programme: $50{ }^{\circ} \mathrm{C}$, held for $1 \mathrm{~min}$, rising at 3 ${ }^{\circ} \mathrm{C} / \mathrm{min}$ to $250{ }^{\circ} \mathrm{C}$, held for $5 \mathrm{~min}$, rising at 2 ${ }^{\circ} \mathrm{C} / \mathrm{min}$ to $280{ }^{\circ} \mathrm{C}$, held for $3 \mathrm{~min}$; injection temperature and volume, $250{ }^{\circ} \mathrm{C}$ and $1.0 \mu \mathrm{l}$, respectively; injection mode, split; split ratio, $30: 1$; carrier gas, nitrogen at $30 \mathrm{~cm} / \mathrm{s}$ linear velocity and inlet pressure $99.8 \mathrm{KPa}$; detector temperature, $280{ }^{\circ} \mathrm{C}$; hydrogen, flow rate, 50 
$\mathrm{ml} / \mathrm{min}$; air flow rate, $400 \mathrm{ml} / \mathrm{min}$; make-up $\left(\mathrm{H}_{2} /\right.$ air $)$, flow rate, $50 \mathrm{ml} / \mathrm{min}$; sampling rate, $40 \mathrm{~ms}$. Data were acquired by means of GC solution software (Shimadzu).

Gas chromatography-mass spectrometry analysis

Agilent $6890 \mathrm{~N}$ GC was interfaced with a VG Analytical 70-250s double - focusing mass spectrometer. Helium was used as the carrier gas. The MS operating conditions were: ionization voltage $70 \mathrm{eV}$, ion source $250{ }^{\circ} \mathrm{C}$. The GC was fitted with a $30 \mathrm{~m} \times 0.32 \mathrm{~mm}$ fused capillary silica column coated with DB-5. The GC operating parameters were identical with those of GC analysis described above.

\section{Insecticidal activity}

The materials used include test insects (Tribolium castaneum and Rhyzopertha dominica), ethanol (99\%), standard insecticide (Permethrin), Petri dish (9 cm diameter), micropipette $(1000 \mu \mathrm{l})$, growth chamber, test sample, filter paper, glass vials, brush.

The insecticidal property of $P$. staudtii essential oil was investigated against Rhyzopertha dominica and Tribolium castaneum in comparison with commercial insecticide Permethrin and ethanol (negative control). In evaluating the insecticidal activity of the volatile oils, a preliminary test was carried out in which several doses, ranging from those having no killing effect on the experiment population to those with a minimum of $100 \%$ killing of this population, were assessed. Using a micropipette (Rainin magnetic assist), the precise volume $(2 \mathrm{~mL})$ of essential oil was added to ethanol $(2 \mathrm{~mL})$ (negative control) and diluted to $5 \mathrm{~mL}$. From this, $0.5 \mathrm{~mL}$ of solution was uniformly applied to a $9 \mathrm{~cm}$ disk of filter paper (Whatman No.1) and placed in a Petri dish. Insects used for the test were reared in glass jars at $27 \pm 1^{\circ} \mathrm{C}$ and $60 \pm 5 \%$ relative humidity $(\mathrm{RH})$ at the laboratory of the H.E.J Research Institute of Chemistry in Karachi, Pakistan.
Twenty adult insects, less than 1 month old, were introduced into the dish 5 min later and the dish was covered. A control with ethanol alone $(2 \mathrm{~mL})$ was made. For each preparation, five replicates were made. The number of dead insects was determined $24 \mathrm{~h}$ after application. Mortality (\%) was calculated as in Eq 1.

$\left.\left(\frac{\text { Mo.of insects alive in test }}{\text { No. of insects alive in control }}\right)(100) \ldots \ldots \ldots 1\right)$

\section{Statistical analysis}

Data are expressed as means \pm s.e.m. Statistical analysis was by one way analysis of variance (ANOVA) and Student's t -test, using SAS 1994, Version 8.2 (SAS Institute, Inc., Cary, NC, USA). The statistical level of significance was $p<0.05$.

\section{Results}

The chemical composition of the leaf essential oil of $P$. staudtii is presented in Table 1. The yield of the essential oil was $1.40(\mathrm{w} / \mathrm{w}) \%$. It was found to be a mixture of mono- and sesqui-terpenoids, and fatty acids. A total of 19 components were identified by their retention indices RI, as well as by GC-MS and other spectroscopic techniques, accounting for $95 \%$ of the oil. Six (6) of the components accounted for the $80 \%$ of the oil (Table 1). The oil comprised of fatty acid derivatives (52 $\%)$, sesquiterpene hydrocarbons (32 \%) caroyphyllene (6 \%), and oxygenated sequiterpenes such as carophylene oxide (5 $\%)$. Monoterpenes hydrocarbons such as phallenden (12\%), pinene (2\%), thujene sp. (2\%), terpinene $(4 \%)$ were also present in the essential oil. Hexadecanoic (30\%) and tetradecanoic (22 \%) acids were major components. The essential oil showed 80 and $60 \%$ insecticidal activity, respectively, (see Table 2) against Rhyzopertha dominica and Tribolium castaneum. 
Falodun et al

Table 1: Composition of essential oil of Pyrenacantha staudtii leaf

\begin{tabular}{|c|c|c|c|}
\hline Compound & & Content (\%) & $\mathrm{RI}$ \\
\hline Thujene sp. & & 0.5 & 923 \\
\hline Camphene & & 0.67 & 945 \\
\hline$\alpha$-Pinene & & 0.5 & 970 \\
\hline$\beta$-Myrecene & & 3.26 & 984 \\
\hline$\alpha$-Phellandrene & & 12.45 & 995 \\
\hline$\Delta^{3}$-Carene & & trace & 1005 \\
\hline p-cymene & & 2.42 & 1012 \\
\hline Limonene & & 1.25 & 1019 \\
\hline Terpene & 3.57 & 1049 & \\
\hline$\beta$ - Caryophyllene & 5.57 & 1464 & \\
\hline Camphor & & 0.23 & 1130 \\
\hline$\beta$-Terpinol-4-ol & & 0.80 & 1161 \\
\hline$\alpha$-Terpineol & & trace & 1172 \\
\hline Methylsalicylate & & 1.35 & 1193 \\
\hline Citronellol sp. & & 7.00 & 1212 \\
\hline$\alpha$-Terpenylacetate & & trace & 1260 \\
\hline$\beta$ - Caryophyllene oxide & & 5.54 & 1565 \\
\hline Hexadecanoic acid & & 28.32 & 1963 \\
\hline Tetradecanoic acid & & 20.60 & 1787 \\
\hline
\end{tabular}

The identification was performed by calculation of retention index (RI) on a $D B-5$ column Trace $<0.1 \%$

Table 2: Insecticidal activity of essential oil of Pyrenacantha staudtii leaf

\begin{tabular}{llc}
\hline Treatment & Conc. $\left(\mu \mathrm{g} / \mathrm{cm}^{3}\right)$ Insecticidal activity $(\%)$ \\
\hline Essential oil & 1019.10 & $60 \pm 1.44(\mathrm{TC})$ \\
Essential oil & 1019.10 & $80 \pm 1.22(\mathrm{RD})$ \\
Permethin(positive control) & 237.5 & $100 \pm 0.00$ \\
Ethanol (negative control) & - & - \\
\hline
\end{tabular}

$$
T C=\text { Tribolium castaneum; } R D \text { = Rhyzopertha dominic; - = no effect }
$$

\section{Discussion}

The insecticidal activity of the essential oil would be dependent on the active chemical constituents and the gross sensitivity of the target pest to the active chemical principles ${ }^{13}$. The volatile oil of $P$. staudtii contains limonene which is reported to be an active insecticidal constituent, that exerts a toxic effect on Coleopterans $^{14}$. The insecticidal activity can be explained, in part, by the high concentration of fatty acids and minor components such as limonene and phallendrene. Thus, the large proportion of fatty acids might have contributed to the activity of the oil against Rhizopertha dominica. This is because, hexadecanoic acid is known to possess a variety of medicinal and pharmacological properties, such as larvicidal effect, on Plasmodium falciparum ${ }^{15}$, and a sex pheromone $^{16}$.

Pesticides are used extensively in agricultural farms, homes and other public places. Resistance to one or more pesiticides has occurred in most major pest species. Relentless development of resistance is a serious threat to the future use of these 
materials, and consequently, there is an urgent need to develop affordable, safe and sound pest control agents and techniques. The essential oil of $P$. staudtii demonstrated some potentials as a new plant insecticide.

\section{Conclusion}

We have determined the chemical composition of the essential oil of leaf of $P$. staudtii leaf by a GC-MS analysis, and have evaluated its insecticidal activity. The results showed that the essential oil was active against the two insects - Tribolium castaneum and Rhyzopertha dominica - tested. However, further studies will need to be undertaken to ascertain fully its bioactivity, toxicity profile, effect on the ecosystem and agricultural products. This will help to establish the synergistic effect of mono- and sesquiterpene hydrocarbon components of the essential oil and its suitability as an insecticide.

\section{Acknowledgements}

The authors are grateful to Third World Academy of Sciences (TWAS) and International Center for Chemical and Biological Sciences (ICCBS) for a Postdoctoral Fellowship Award to A.F. The interest and support of Professor E.O.P. Agbakwuru, formerly of the University of Benin, is gratefully acknowledged.

\section{References}

1. Baladrin MF, Kinghorn AD, Farnsworth NR. Plants derived natural products in drug discovery and Development. In Human medicinal Agents from Plants, Symposium Series 534, Baladrin MF (Ed.). American Chemical Society, Washington DC. 1993, pp 2-12.

2. Farnsworth NR. Screening Plants for New Medicines. In Biodiversity. Wilson EO, Peter FM (Eds.) National Academy Press, Washinghton DC 1988, pp $83-96$.

3. Atta-ur-Rahman, Choudhary MI, William, JT. Bioassay techniques for drug development. Harward Academic Publisher, 1997, pp 67- 68.
4. Aguwa CN, Okunji, CO. Gastrointestinal Studies of Pyrenacantha staudtii Leaf Extracts. Eur. J. Pharmacol. 1986; $15: 45$ - 55.

5. Gill LS. In: Gills, L.S.(Ed.), Ethnomedical Uses of Plants in Nigeria. Uniben Press, 1992; p. 143.

6. Mesia Gk, Tona Gl Penge O, Lusakabanza M, Nanga TM, Cimanga RK, Apers S Van Miert S, Totte J, Rieters L, Vlietinck AJ. Antimalarial Activities and Toxicities of Three Plants Use in the Democratic Republic of Congo: Croton Mubango, Nauclea pobeguinii and Pyrenacantha staudtii. Ann. Trop. Med. Parasitol. 2005; 99(4): 345 - 7.

7. Falodun A, Usifoh CO, Nworgu ZAM. Phytochemical and active column fractions of Pyrenacantha staudtii leaf extract on isolated rat uterus. Pak.J. Pharm. Sci. 2005; 18(4) 31 -35.

8. Falodun A, Usifoh CO. Isolation and Characterization of 3-carbomethoxypyridine from the leaves of Pyrenacantha staudtii (Hutch and Dalz). Act. Pol Pharm Drug Res. 2006; 63 (3) 235 -237.

9. Adams RP. Identification of Essential oils by Gas Chromatography Quadrupole Mass Spectrometry. Allured Publishing Corpoartion, Carol Stream, USA, 2001

10. Adams RP. Identification of Essential oils by Ion Trap Mass Spectroscopy. Academic Press, New York, 1989.

11. British Pharmacopoeia. H.M. Stationary Office, London, II, P.A. 1980, p 109.

12. Julain $D$, Konig WA. The atlas of spectral data of sesquiterpene hydrocarbons. Verlag, Harburg, 1988.

13. Obeng $O D$, Reichmuth $C$, Bekele J, Hassanali $A$. Biological Activity of 1,8 cineole, a major component of essential oil of Ocimum kenyense (Ayobengina) against stored products beetles. J. Appl. Entomol. 1997; 121: 237 243.

14. Tanpojou LA, Adler C, Bouda H, Fountern DA. Efficacy of powder and essential oil from Chinopodium ambrossioides leaves as post harvest grain protectants against six stored product beetles. J. Stored Prods. Res. 2002; 38: 395 - 402

15. Guoqing L, Zhaojun H, Lili M, Xiaron Q, Changkun $C$, Yinchang $W$. Natural Oviposition-deterring chemicals in female cotton bollworm, Hellicoverpa armigera (Hubner). J. Insect Physiol.2001; 47: 951 - 956.

16. Fu X, Fujuzawa M, Tabata J, Taksuki S, Ishikawa Y. Sex Pheromone biosynthesis in Ostrinia zaguliaevi, a congener of the European corn borer moth 0 . nubilalis. Insect Biochem. Mol. Biol. 2005; 35: 621 - 956. 